(RESEARCH ARTICLE)

\title{
Ethnobotanical study of medicinal plants used in the treatment of sexual dysfunctions in traditional medicine in Kampemba-Lubumbashi, DR Congo
}

Bashige Chiribagula Valentin 1, 2, ${ }^{*}$, Alombong Alonie Gracia 2, Kamwimba Mahungala Arlette 2, Bakari Amuri Salvius ${ }^{1}$ and Okusa Ndjolo philippe ${ }^{2}$

${ }^{1}$ Laboratoire de Pharmacognosie - Faculté des Sciences Pharmaceutiques - Université de Lubumbashi - 27, av Kato, Commune Kampemba, Lubumbashi -DR Congo.

2 Service de Chimie thérapeutique-Faculté des Sciences Pharmaceutiques - Université de Lubumbashi - 27, av Kato, Commune Kampemba, Lubumbashi -DR Congo.

Publication history: Received on 25 August 2020; revised on 03 September 2020; accepted on 06 September 2020

Article DOI: https://doi.org/10.30574/wjarr.2020.7.3.0328

\begin{abstract}
For a long time, vegetation has provided man with remedies to deal with his health problems such as erectile dysfunction. This study was conducted to inventory plants and recipes used in traditional medicine in Kampemba (Lubumbashi) in the treatment of sexual dysfunctions. This descriptive ethnobotanical survey was carried out between October 2017 and June 2018. It was conducted by direct interview using a guide questionnaire with 34 practitioners of traditional medicine (PMT). The 34 PMT consulted were mainly men (sex ratio Man / Women = 2.09) aged $49 \pm 11$ years. They provided information on 51 recipes and 33 plants among which only 21 species have been scientifically identified. Albizia adianthifolia (Schum.) W. Wight (Fabaceae) and Pericopsis angolensis (Baker) Meeuwen (Fabaceae) are the most cited species. These 21 plants are mostly trees (57\%) belonging to 12 families dominated by Fabaceae $(21.2 \%)$ and indicated in 22 pathologies dominated by sexual impotence with a fidelity level (FL) of 0.59 . From these plants derive 37 recipes from which the root is the most used organ (75.7\%). The decoction (45.9\%) and the drink (78.4\%) are respectively the methods of preparation and administration route most requested. This study reports for the first time the aphrodisiac use of 8 plants among which, Schrebera trichoclada Welw (Oleaceae), Strychnos stuhlmannii Gilg (Loganiaceae) and Terminalia mollis MA Lawson (Combretaceae) have the highest fidelity index (FL) (FL> 0.1). Kampemba PMTs know and use aphrodisiac plants whose investigations deserve to be continued to validate their traditional knowledge.
\end{abstract}

Keywords: Aphrodisiacs; Medicinal plants; Kampemba; DR Congo; Sexual impotence

\section{Introduction}

Sexual dysfunction is a disturbance that can alter the cycle of sexual response to one of its four phases: arousal, plateau, orgasm, and resolution. There are several types of sexual dysfunction of which anorgasmia, sexual aversion, dyspareunia, premature ejaculation, delayed ejaculation, frigidity, impotence and vaginismus are the most common [1].

The prevalence of sexual dysfunction is estimated between 10 and $50 \%$ in men [2], but it is higher in women: 25 to $63 \%$ $[3,4]$ in the world. A review of the literature over 10 years from 1999 to 2009) has established a prevalence of 0 to $3 \%$ of male orgasmic dysfunctions, 0 to $5 \%$ of erectile dysfunctions and 0 to $3 \%$ of dysfunctions of male hypoactive sexual desire, from 7 to $10 \%$ of female orgasmic dysfunctions and 4 to $5 \%$ premature ejaculation [5].

\footnotetext{
${ }^{*}$ Corresponding author: Bashige Chiribagula Valentin

Laboratoire de Pharmacognosie - Faculté des Sciences Pharmaceutiques - Université de Lubumbashi - 27, av Kato, Commune Kampemba, Lubumbashi -DR Congo.
} 
Several types of treatment are claimed in modern medicine against these different dysfunctions. However, most of these drugs have significant side effects and limits in meeting sexual needs; moreover they are costly [6,7]. Thus, in developing countries, most of the patients who have sexual dysfunction resort first to traditional medicine which provides several plants used for this purpose [8]. This is the case of Allium sativum L, Liliaceae [9], Anacardium occidentale L., Anacardiaceae [10], Chenopodium album L., Amaranthaceae [11], or Kaempferia parviflora Wall. ex Baker, [12]. In the city of Kampemba as in several cities of the Democratic Republic of Congo (DRC), several people use plants against sexual dysfunctions.

This study deals with the inventory and the identification of plants used in traditional Congolese medicine in Kampemba against sexual dysfunctions.

\section{Material and methods}

\subsection{Area of study}

This descriptive ethnobotanical study was conducted in the city of Kampemba (Figure 1), located between $11^{\circ} 38-39^{\prime}$ South and $27^{\circ} 28-29^{\prime}$ East in Lubumbashi in DRC, with an area of $48 \mathrm{~km}^{2}$, an altitude of 1,267 m and 306,591 inhabitants. The City of Kampemba has 8 districts including, Bel-air I, Bel-air II, Bongonga, Industriel, Kafubu, Kinkaville, Kampemba, and Kigoma located in the Miombo clear forest.
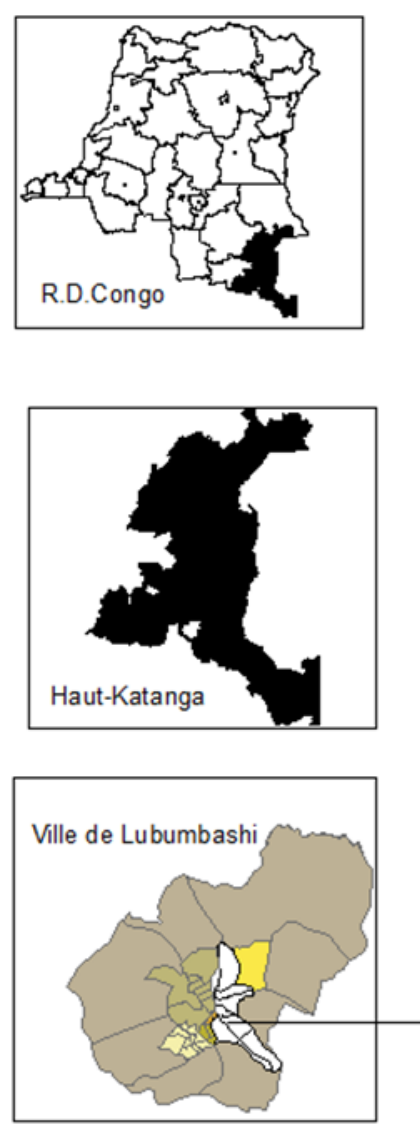

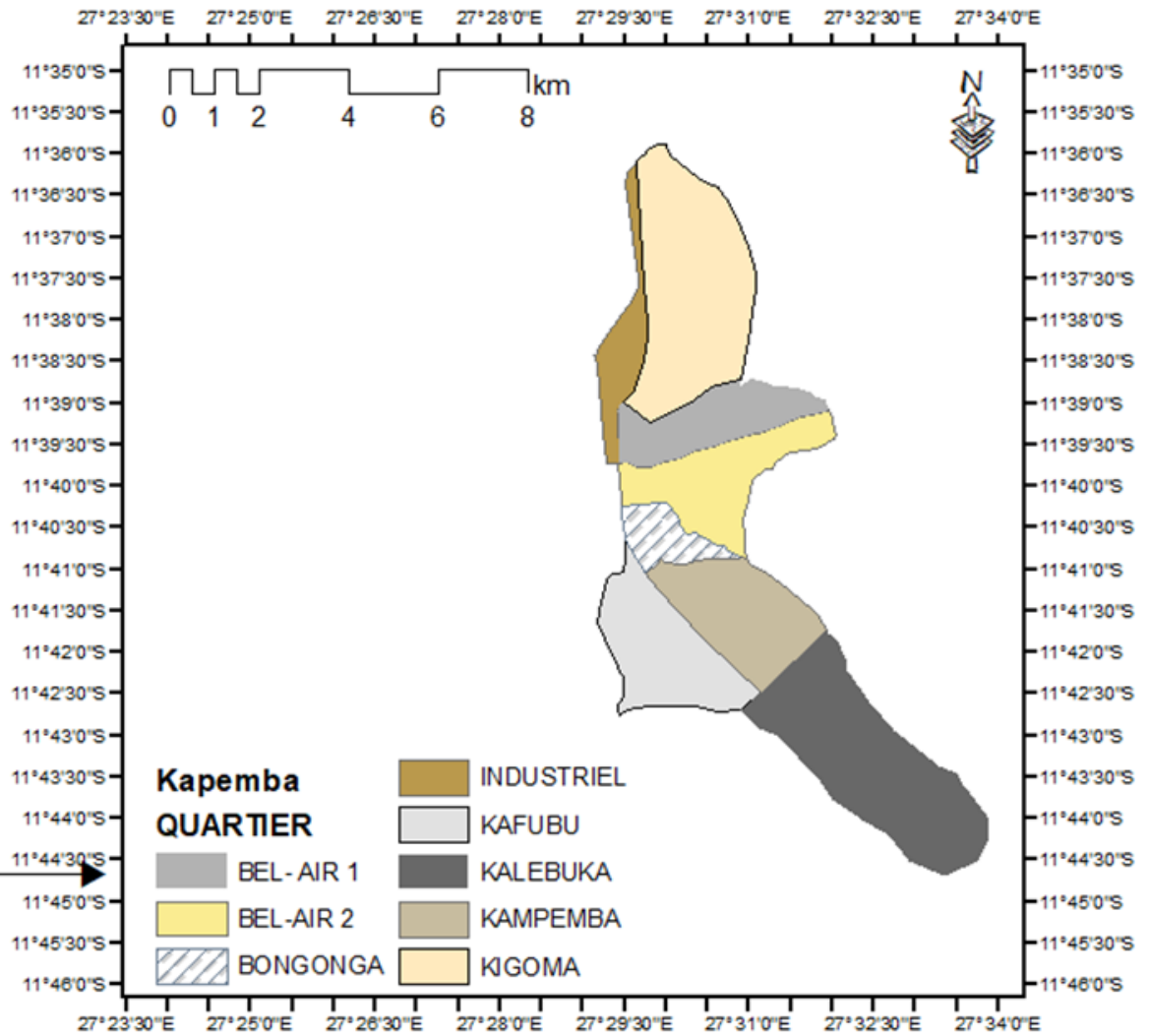

Figure 1 Map of Kampemba City.

\subsection{Ethnobotanical data collection}

The ethnobotanical data were collected between October 2017 and June 2018 from traditional medicine practitioners (TMP) of the Kampemba city by direct interview using a guide questionnaire comprising 16 items. These focused mainly on the characteristics of informants (TMP) and data relating to plants used in the management of sexual dysfunction. The choice of TMP was based on their popularity in their Kampemba municipality and their willingness to share their knowledge with the investigators. The investigations were carried out in all the districts of Kampemba. Inventoried 
plants were collected along with PMT and an herbarium was established for each plant for further identification at the Kipopo herbarium where the identity of the plant was determined.

\subsection{Data analysis}

Socio-cultural characteristics of informants, flora, and ethnobotany of the plants made it possible to analyze the data collected and processed by the Excel software 2016. Three ethnobotanical indices were calculated to assess the significant species: The relative frequencies of citation ( $\mathrm{Fi}(\%)=\mathrm{n} \times 100 / \mathrm{N}$ or $\mathrm{Fi}=\mathrm{n} / \mathrm{N}$ ), the usual value (UV $=\sum \mathrm{Ui}$ / $\mathrm{N})$, the level of relative fidelity $(\mathrm{FL}=\mathrm{np} / \mathrm{N})$ and the consensus factor of the informant $(\mathrm{FCI}=(\mathrm{Nur}-\mathrm{Nt}) /(\mathrm{Nur}-1))$ as previously described [13]; With $\mathrm{n}=$ number of times that the character is cited and $\mathrm{N}=$ number of informants, $\mathrm{Ui}=$ Number of uses indicated by the informant $i, n p=$ number of informants who indicated a species for a use $p$, Nur = number of times a particular category of a condition has been mentioned, $\mathrm{Nt}=$ Number of plants mentioned for the treatment of this condition m. UV: used to assess the medicinal importance of a plant in the study environment, FL: used to identify the level of consensus on the use of a plant for a given indication in our study environment; FCI: establishes a consensus of informants on a given medicinal use of medicinal plants used in the study environment.

\section{Results and discussion}

\subsection{Socio-demographic characteristics of the PMT consulted}

The ethnobotanical survey was conducted in 8 districts of the Kampemba city in Lubumbashi (DRC) with 34 PMTs, many of them were men (sex ratio $=2.09$ ), with an average age of 49 years (extremes: 31 and 73 years) and an average experience of practice in the traditional medicine of 18 years (extremes: 1 and 25 years). Most informants live in Bongonga (38.3\%) and Kafubu (26.5\%) and are identified in the category of healers (76.5\%). They did not go beyond primary education $(79.4 \%)$ and most of them acquired their knowledge from their ancestors $(70.6 \%)$. Although the majority are Bemba (29.4\%) and Luba (38.3\%) and all speak Swahili (Table 1).

Table 1 Socio-demographic characteristics of practitioner of traditional medicine (PMT)

\begin{tabular}{llll}
\hline Class & Sub-Class & Ei & Fi (\%) \\
\hline Age & {$[18-27]$} & 3 & 8.9 \\
& ] $27-37]$ & 2 & 5.9 \\
& ] $37-47]$ & 6 & 17.6 \\
& ] $47-57]$ & 20 & 58.8 \\
Experience (year) & $>57$ & 3 & 8.8 \\
& {$[1-5]$} & 2 & 5.9 \\
Gender & {$[6-10]$} & 2 & 5.9 \\
Studies & {$[11-15]$} & 2 & 5.9 \\
& {$[16-20]$} & 18 & 52.9 \\
& {$[21-25]$} & 10 & 29.4 \\
& Women & 11 & 32.4 \\
Category & Man & 23 & 67.6 \\
& Graduate & 2 & 5.9 \\
& Postgraduate & 1 & 2.9 \\
& Primary & 21 & 61.8 \\
& No formal instruction & 6 & 17.6 \\
& Professional & 4 & 11.8 \\
& Witch & 2 & 5,9 \\
& Healer & 26 & 76.5
\end{tabular}


World Journal of Advanced Research and Reviews, 2020, 07(03), 016-032

\begin{tabular}{|c|c|c|c|}
\hline Class & Sub-Class & $\mathbf{E i}$ & Fi (\%) \\
\hline & Traditional healer & 6 & 17.6 \\
\hline \multirow[t]{5}{*}{ Traditional Medicine learning pathway } & Dream & 3 & 8.8 \\
\hline & Spirits & 2 & 5.9 \\
\hline & Ancestors & 24 & 70.6 \\
\hline & Another healer & 4 & 11.8 \\
\hline & Self-Study & 1 & 2.9 \\
\hline \multirow[t]{8}{*}{ Ethnicity } & Bemba & 9 & 26.5 \\
\hline & Hemba & 2 & 5.9 \\
\hline & Kusu & 1 & 2.9 \\
\hline & Lamba & 3 & 8.8 \\
\hline & Luba & 13 & 38.3 \\
\hline & Rund & 3 & 8.8 \\
\hline & Tabwa & 2 & 5.9 \\
\hline & Tshokwe & 1 & 2.9 \\
\hline \multirow[t]{11}{*}{ Spoken languages } & Bemba & 10 & 29.4 \\
\hline & French & 4 & 11.8 \\
\hline & Hemba & 4 & 11.8 \\
\hline & Kusu & 5 & 14.7 \\
\hline & Lamba & 6 & 17.6 \\
\hline & Luba & 18 & 52.9 \\
\hline & Rund & 13 & 38.2 \\
\hline & Swahili & 34 & 100 \\
\hline & Tabwa & 6 & 17.6 \\
\hline & Tshiluba & 10 & 29.4 \\
\hline & Tshokwe & 1 & 2.9 \\
\hline \multirow[t]{8}{*}{ Habitation municipality } & Bel-air I & 3 & 8.8 \\
\hline & Bel-air II & 3 & 8.8 \\
\hline & Bongonga & 13 & 38.3 \\
\hline & Industriel & 1 & 2.9 \\
\hline & Kafubu & 9 & 26.5 \\
\hline & Kinka-ville & 2 & 5.9 \\
\hline & Kampemba & 1 & 2.9 \\
\hline & Kigoma & 2 & 5.9 \\
\hline
\end{tabular}




\subsection{General characteristics of the plants listed}

\subsubsection{Morpho-biological types, Phytogeographical distribution and Harvest site of identified plants}

Only 21 out of 33 species cited during the survey as aphrodisiacs, were formally identified at the Kipopo herbarium. The identified plants were collected in 5 of the 8 districts of the Kampemba city, more than half of them were found in Kafubu (52\%). The collected plant species have been divided into 3 morphological types dominated by trees (57\%), 4 biological types dominated by Mesophanerophytes: $\mathrm{MePh}$ (55\%), and 4 types of phytogeographic distribution, wherefrom Tropical Africa: TA, is the major distribution type with 38\% (Figure 2).
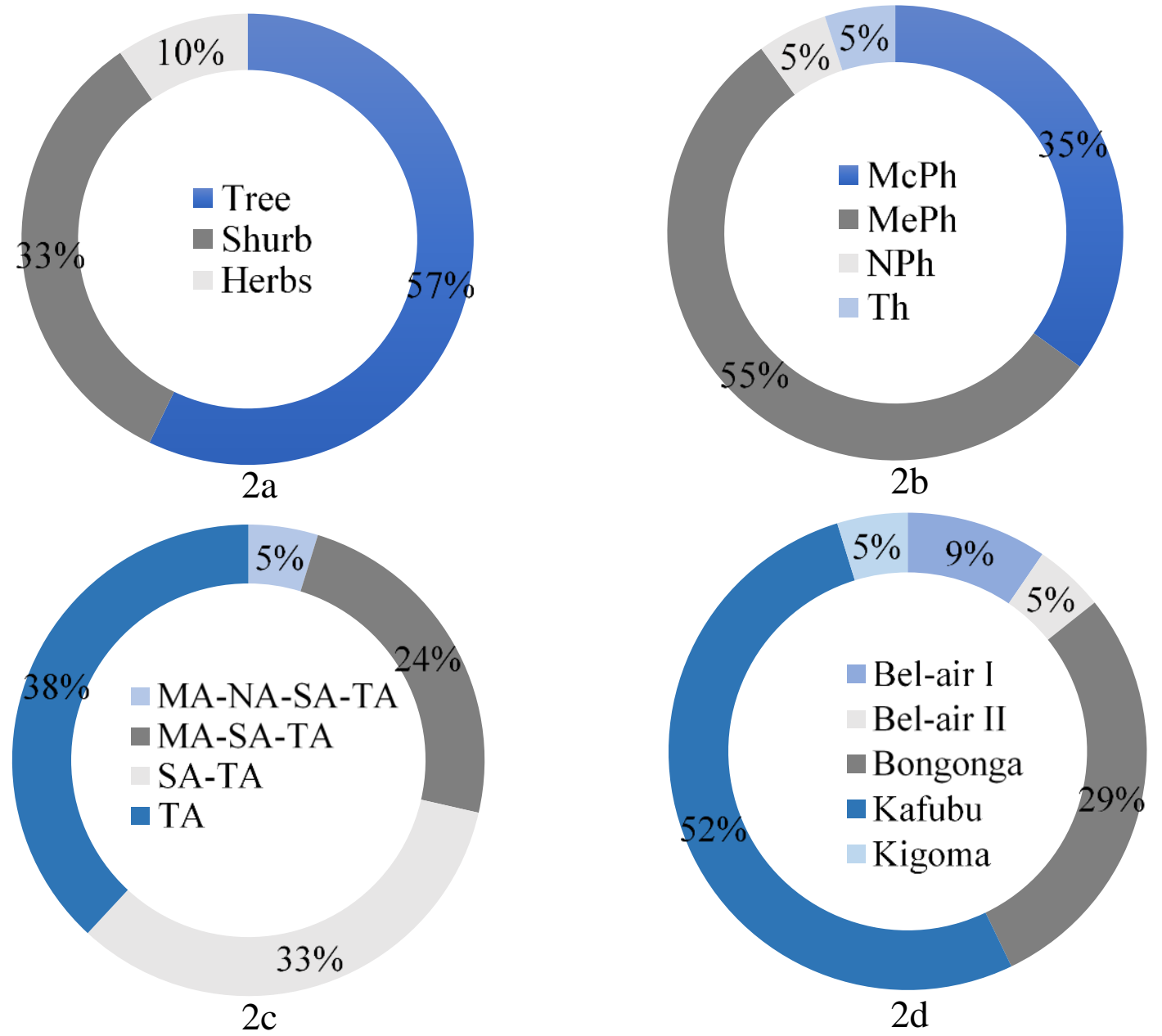

Figure 2 Plant characteristics: Morphological types (a), Biological types (b), Phytogeographical distribution (c) and Harvest site $(\mathrm{d})$.

\subsubsection{Botanical information, Identification in the vernacular and classification of scientifically identified plants}

The 21 plants identified botanically during this study belong to 20 genera divided into 12 families dominated by Fabaceae with 7 species (Figure 3a) and identified in 4 vernacular languages dominated by Bemba (53\%) and for which only Tshiluba is a language not native to the region (Figure 3b). 4 types of sexual dysfunction are handled of by the PMTs consulted, of which the third (35\%) deals with sexual impotence (Figure 3c). Regarding the literature, these plants can be grouped into 4 classes, most of the plants belonging to class $\mathrm{A}$, the one which includes plants both used in the region as aphrodisiacs and medicinal (Figure $3 \mathrm{~d}$ ). 

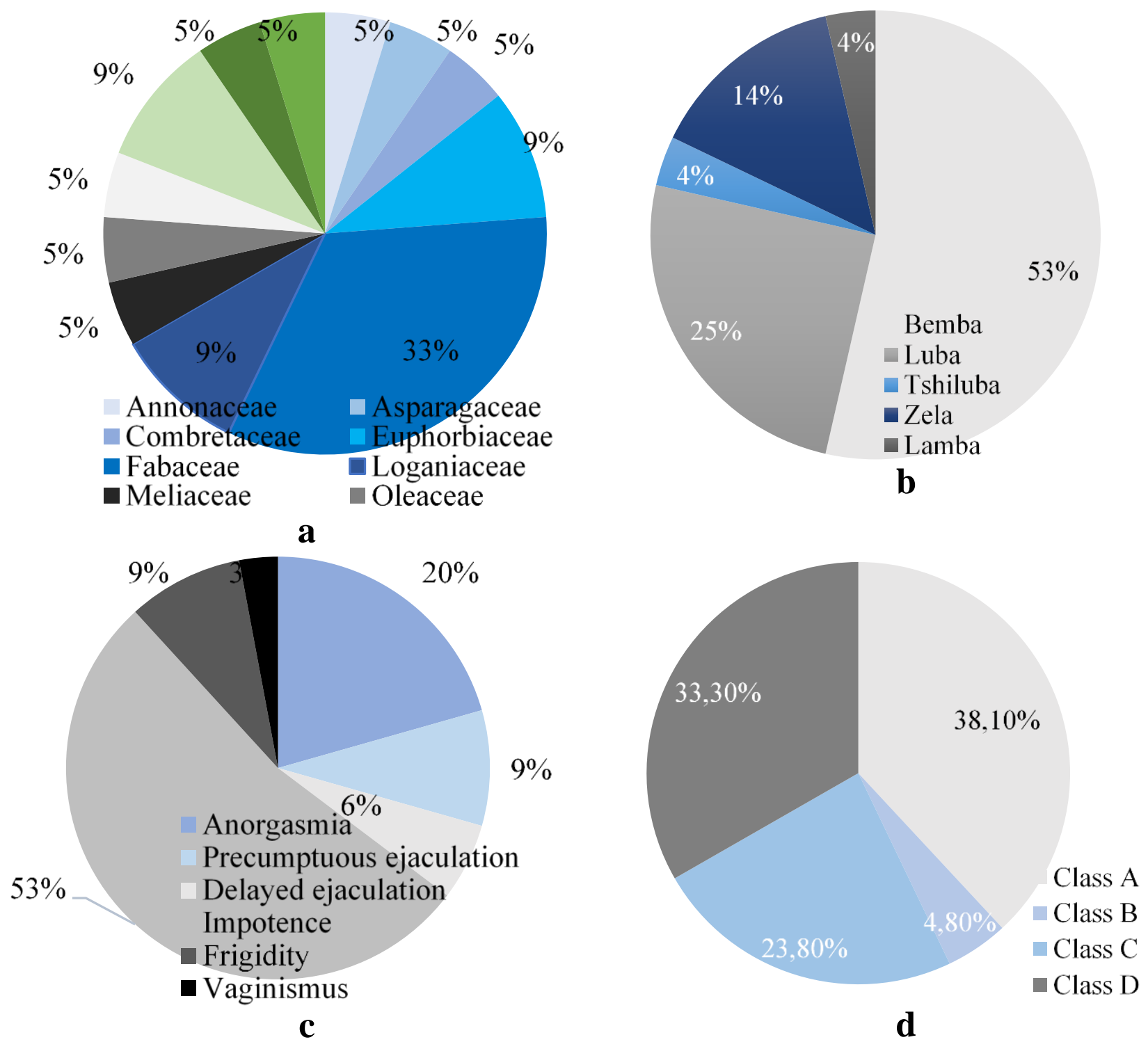

Figure 3 Plant characteristics: botanical families (a), Nomenclature of plants in vernacular names (b), Sexual dysfunctions treated (c) and Classification of different species according to literature (d). Class A: Plants both recognized in the literature as regional medicines and aphrodisiacs; Class B: Plants never reported as medicinal in the literature, Class C: Plants reported in the literature as an aphrodisiac but not recognized as medicinal in the region, Class D: Plants reported in the literature as used only in the traditional medicine of the region.

Among the 21 species, Erythrina abyssinica Lam. ex DC. (Fabaceae) has the highest use value (UV) among the different types of sexual dysfunction but it is Albizia adianthifolia (Schum.) W. Wight and Pericopsis angolensis (Baker) Meeuwen (Fabaceae) which have a better citation fidelity index (FL) in sexual dysfunctions. The two plants are both recognized as aphrodisiacs and medicinal plants from Haut-Katanga (Table 2). 
Table 2 Nomenclature of plants in vernacular names and characteristics of plants by botanical index relating to aphrodisiac use.

\begin{tabular}{|c|c|c|c|c|c|c|}
\hline Plant species (Family) & KHC & NoVer & RAPU & CAMPK & FLAP & UV \\
\hline $\begin{array}{l}\text { Albizia adianthifolia (Schum.) W. Wight } \\
\text { (Fabaceae) }\end{array}$ & НК00126 & $\begin{array}{l}\text { Kapentazovu } \\
\text { (Bemba) }\end{array}$ & [14] & [15] & 0.58 & 0.25 \\
\hline Annona senegalensis Pers (Annonaceae) & HK00128 & Mulolo (Bemba) & [16] & [17] & 0.06 & 0.5 \\
\hline Antidesma venosum Tul (Euphorbiaceae) & HК00127 & Kifobia (Luba) & [18] & [19] & 0.12 & 1 \\
\hline & & Kifuvia (Bemba) & & & & \\
\hline Asparagus plumosus Bak. (Asparagaceae) & НК00129 & $\begin{array}{l}\text { Kenyeshinde } \\
\text { (Bemba) }\end{array}$ & [20] & & 0.06 & 0.5 \\
\hline $\begin{array}{l}\text { Bobgunnia madagascariensis } \\
\text { (Desv) JH Kirkbr (Fabaceae) }\end{array}$ & НК00130 & $\begin{array}{l}\text { Ndale } \\
\text { (Bemba,Luba) }\end{array}$ & & [21] & 0.09 & 0.33 \\
\hline Senna petersiana Bolle (Fabaceae) & HK00131 & $\begin{array}{l}\text { Kafungunasha } \\
\text { (Bemba) }\end{array}$ & {$[22]$} & [19] & 0.06 & 0.5 \\
\hline $\begin{array}{l}\text { Crossopteryx febrifuga (Afzel. ex G.Don) } \\
\text { Benth (Rubiaceae) }\end{array}$ & HK00132 & $\begin{array}{l}\text { Mutambelungu } \\
\text { (Zela) } \\
\text { Konsekonse } \\
\text { (Bemba) }\end{array}$ & & [18] & 0.03 & 2 \\
\hline $\begin{array}{l}\text { Ekebergia benguelensis Welw. Ex.CDC } \\
\text { (Meliaceae). }\end{array}$ & НК00134 & $\begin{array}{l}\text { Mubundikwa } \\
\text { (Bemba) }\end{array}$ & [24] & & 0.09 & 1 \\
\hline $\begin{array}{l}\begin{array}{l}\text { Erythrina abyssinica } \\
\text { (Fabaceae) }\end{array} \\
\text { Lam. ex }\end{array}$ & НК00136 & $\begin{array}{l}\text { Kisengwe } \\
\text { (Bemba) }\end{array}$ & & [17] & 0.03 & 5 \\
\hline Fagara zanthoxyloides Lam (Rutaceae) & HК00138 & Pupue (Lamba) & [25] & & 0.06 & 0.5 \\
\hline $\begin{array}{l}\text { Gardenia jovis-Tonantis (Welw) Hiern } \\
\text { (Rubiaceae) }\end{array}$ & НК00141 & Kolweba (Zela) & [26] & & 0.06 & 1 \\
\hline Hymenocardia acida Tull (Euphorbiaceae) & НК00142 & Pepe (Bemba) & [27] & [28] & 0.06 & 1 \\
\hline $\begin{array}{l}\text { Julbernardia paniculata (Benth.) Troupin } \\
\text { (Fabaceae) }\end{array}$ & НК00143 & Mutondo (Luba) & & & 0.03 & 2 \\
\hline $\begin{array}{l}\text { Pericopsis angolensis (Baker) Meeuwen } \\
\text { (Fabaceae) }\end{array}$ & НК00144 & $\begin{array}{l}\text { Mubanga (Luba) } \\
\text { Munika } \\
\text { Munyenze } \\
\text { (Hemba) }\end{array}$ & [29] & [19] & 0.56 & 0.25 \\
\hline Physalis angulata L. (Solanaceae) & НК00145 & $\begin{array}{l}\text { Musongwa (Zela) } \\
\text { Musonge } \\
\text { (Bemba) } \\
\text { Makukwe (Luba) }\end{array}$ & [30] & & 0.06 & 0.5 \\
\hline Pterocarpus tinctorius Welw (Fabaceae) & НК00146 & Kakula (Luba) & & [19] & 0.03 & 2 \\
\hline Schrebera trichoclada Welw (Oleaceae) & НК00147 & Mutoba (Bemba) & & [21] & 0.18 & 0.5 \\
\hline $\begin{array}{l}\text { Securidaca longipedunculata Fresen } \\
\text { (Polygalaceae) }\end{array}$ & HК00149 & $\begin{array}{l}\text { Mwimba } \\
\text { (Bemba) }\end{array}$ & {$[31]$} & [17] & 0.06 & 1 \\
\hline & & Mweyeye (zela) & & & & \\
\hline Strychnos cocculoides Baker (Loganiaceae) & HK00151 & Nzanza (Bemba) & [32] & [19] & 0.15 & 0.4 \\
\hline Strychnos stuhlmannii Gilg (Loganiaceae) & HK00152 & $\begin{array}{l}\text { Mubanga kyulu } \\
\text { (bemba) }\end{array}$ & & [19] & 0.24 & 0.38 \\
\hline $\begin{array}{l}\text { Terminalia mollis } \\
\text { (Combretaceae) }\end{array}$ & НК00153 & $\begin{array}{l}\text { Kibobo (Luba) } \\
\text { Mboumbou } \\
\text { (Tshiluba) }\end{array}$ & & [19] & 0.12 & 0.5 \\
\hline
\end{tabular}

NoVer: Vernacular Name, KHC: Kipopo herbarium code, RAPU: Reference of aphrodisiac use, CAMPK: Citation as a medicinal plant from Katanga, $\mathbf{F L}_{\mathrm{AP}}$ : Fidelity level of aphrodisiac use $=\mathrm{FL}=\mathrm{np} / \mathrm{N}$ where $\mathrm{np}=$ number of informants who mentioned a species for use, $\mathrm{N}=$ number of informants. 


\subsubsection{Aphrodisiac recipes from 21 identified plants}

From 21 plants derive 37 recipes where the root $(75.7 \%)$ is the most used organ alongside the leaves, stems and, mixtures of these 3 organs. These recipes are prepared according to 7 modes dominated by the decoction (45.9\%) and administered in most cases in the form of a drink (78.4\%) alongside the bath, the dough, and the steam (Figure 4).

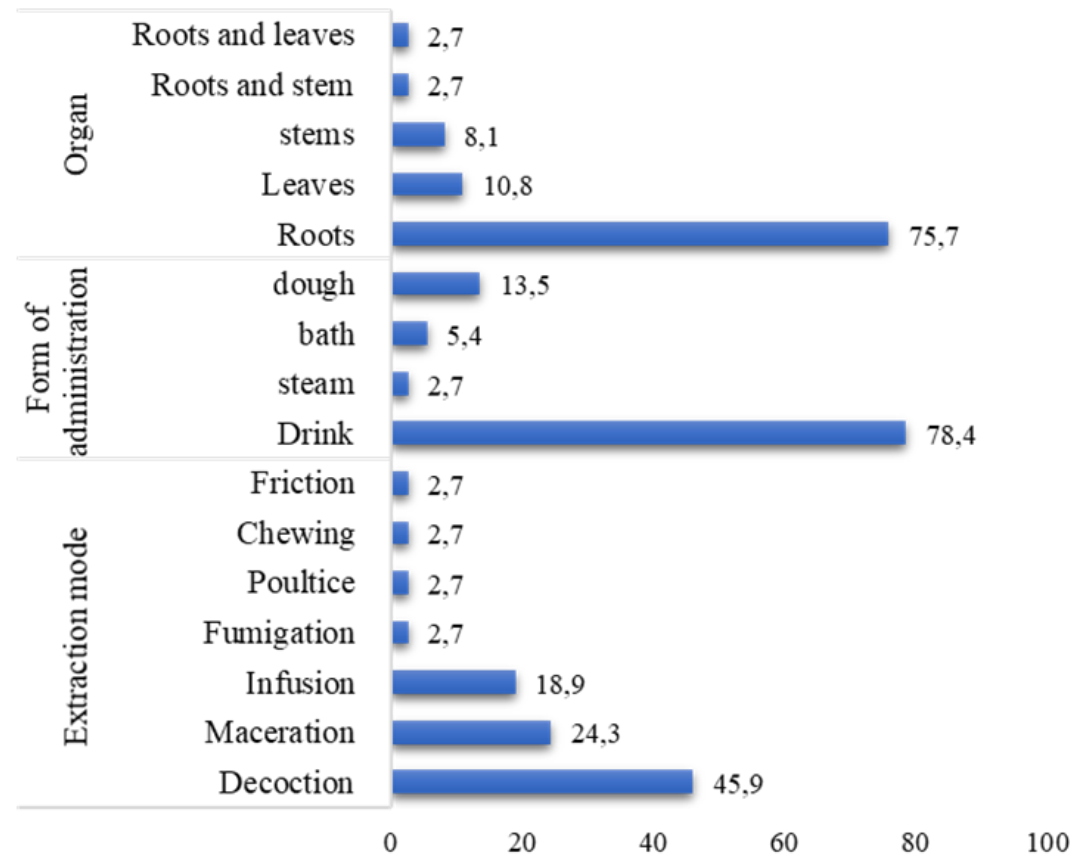

Figure 4 Characteristics of the aphrodisiac recipes of 21 plants identified during the survey.

Albizia adianthifolia and Pericopsis angolensis have the highest usual values (UV =13.4) plants (Table 3). The R14 recipe based on the roots of Crossopteryx febrifuga, has the highest relative citation frequency (Fi $=2$ ). Fourteen other recipes (37.8\%) based on the roots of Albizia adianthifolia, have a Fi of 1 . R1 (FL = 0.20) and R2 (FL $=0.23)$. R24 (FL $=0.26)$ based on the roots of Pericopsis angolensis, R1 and R2 constitute the 3 recipes with the highest consensual level (FL) in surveyed informants (Table 3).

Table 3 Indications of identified plants, aphrodisiac recipes, and their characteristics

\begin{tabular}{|c|c|c|c|c|c|c|c|}
\hline $\mathbf{N}^{0}$ & Plant species & Aphrodisiac recipe & $\mathbf{F i}$ & FL $L_{A P}$ & Indications & & $\mathbf{U V}_{\mathbf{P}}$ \\
\hline \multirow[t]{5}{*}{1} & $\begin{array}{l}\text { Albizia } \\
\text { adianthifolia }\end{array}$ & $\begin{array}{l}\text { R1: Decoction for } 30 \text { minutes of about } 18 \mathrm{~g} \\
\text { of dry root powder in } 2 \mathrm{~L} \text { of water. Drink } 1 / 2 \\
\text { cup } 3 \mathrm{x} / \text { Day. }\end{array}$ & 0.35 & 0.2 & $\begin{array}{l}\text { Diabetes, } \\
\text { acne, } \\
\text { impotence }\end{array}$ & $\begin{array}{l}\text { fever, } \\
\text { sores, }\end{array}$ & 13.4 \\
\hline & & $\begin{array}{l}\mathrm{R} 2 \text { : Decoction for } 30 \text { minutes of } 18 \mathrm{~g} \text { of fresh } \\
\text { root powder in } 2 \mathrm{~L} \text { of water. Drink } 1 / 2 \text { cup } \\
3 \mathrm{x} / \text { Day. }\end{array}$ & 0.4 & 0.23 & & & \\
\hline & & $\begin{array}{l}\text { R3: Infusion of a handful of fresh leaves in } \\
\text { 1.5L of water. Let cool, drink } 1 / 2 \text { cup } 2 x / \\
\text { Day. }\end{array}$ & 0.2 & 0.11 & & & \\
\hline & & $\begin{array}{l}\text { R4: Maceration of } 50 \mathrm{~g} \text { of the ground roots } \\
\text { in } 1 \text { liter of water for } 24 \text { hours. Drink } 1 \text { glass } \\
2 \mathrm{x} / \text { Day }\end{array}$ & 0.15 & 0.08 & & & \\
\hline & & $\begin{array}{l}\text { R5: Infusion of a handful of fresh leaves in } \\
\text { 1.5L of water. Let cool, drink } 1 / 2 \text { cup } \\
2 x / \text { Day. }\end{array}$ & 0.2 & 0.11 & & & \\
\hline
\end{tabular}




\begin{tabular}{|c|c|c|c|c|c|c|}
\hline $\mathbf{N}^{0}$ & Plant species & Aphrodisiac recipe & $\mathbf{F i}$ & FLaP & Indications & $\mathbf{U V}_{\mathbf{P}}$ \\
\hline \multirow[t]{2}{*}{2} & $\begin{array}{l}\text { Annona } \\
\text { Senegalensis }\end{array}$ & $\begin{array}{l}\text { R6: Infusion of } 20 \mathrm{~g} \text { of dry root powder in } 2 \mathrm{~L} \\
\text { of water. Drink } 1 / 2 \text { cup } 3 \mathrm{x} / \text { Day. }\end{array}$ & 0.5 & 0.02 & $\begin{array}{l}\text { Impotence, } \\
\text { Headache }\end{array}$ & 0.5 \\
\hline & & $\begin{array}{l}\text { R7: Maceration for } 24 \text { hours in } 1 \mathrm{~L} \text { of water } \\
\text { from } 20 \mathrm{~g} \text { of stem bark powder. Drink } 1 / 2 \\
\text { cup } 3 \mathrm{x} / \text { Day. }\end{array}$ & 1 & 0.05 & & \\
\hline 2 & $\begin{array}{l}\text { Antidesma } \\
\text { Venosum }\end{array}$ & $\begin{array}{l}\text { R8: Fumigation for } 15 \text { minutes of an } \\
\text { aqueous decoction of } 3 \text { handfuls of root bark } \\
\text { before acting. }\end{array}$ & 1 & 0.11 & $\begin{array}{l}\text { Anorgasmia, fever, } \\
\text { constipation, sores }\end{array}$ & 2 \\
\hline 4 & $\begin{array}{l}\text { Asparagus } \\
\text { plumosus }\end{array}$ & $\begin{array}{l}\text { R9: Decoction for } 1 \text { hour of } 40 \mathrm{~g} \text { of dry root } \\
\text { powders in } 1 \mathrm{~L} \text { of water. Drink } 1 / 2 \text { glass } 3 \mathrm{x} / \\
\text { Day. }\end{array}$ & 1 & 0.05 & $\begin{array}{l}\text { Impotence, } \\
\text { headache }\end{array}$ & 0.5 \\
\hline \multirow[t]{3}{*}{5} & $\begin{array}{l}\text { Bobgunnia } \\
\text { madagascariensis }\end{array}$ & $\begin{array}{l}\text { R10: Local application of a handful of root } \\
\text { bark powder soaked in } 100 \mathrm{~mL} \text { of palm oil } \\
15 \text { minutes before acting. }\end{array}$ & 1 & 0.08 & Sexual impotence & 0.4 \\
\hline & & $\begin{array}{l}\text { R11: Maceration in } 3 \mathrm{~L} \text { of water for } 48 \text { hours, } \\
\text { a handful of root bark powder, drink } 1 \text { cup a } \\
\text { few minutes before the act. }\end{array}$ & 0.75 & 0.05 & & \\
\hline & & $\begin{array}{l}\text { R12: Maceration of } 500 \mathrm{~g} \text { of leaves in } 10 \mathrm{~L} \text { of } \\
\text { water for } 24 \text { hours. wash with maceration } 2 \\
\text { hours before acting. }\end{array}$ & 0.33 & 0.02 & & \\
\hline 6 & Senna petersiana & $\begin{array}{l}\text { R13: Maceration of } 5 \mathrm{~g} \text { of dry root bark } \\
\text { powder in } 1 \mathrm{~L} \text { of any drink for } 24 \text { hours. } \\
\text { Drink } 1 / 2 \text { glass } 2 \text { or } 3 \mathrm{x} / \text { Day. }\end{array}$ & 1 & 0.05 & Sexual impotence & 0.3 \\
\hline \multirow[t]{2}{*}{7} & $\begin{array}{l}\text { Crossopteryx } \\
\text { febrifuga }\end{array}$ & $\begin{array}{l}\text { R14: Decoction of two handfuls of root } \\
\text { powder in } 2.5 \mathrm{~L} \text { of water for } 40 \text { minutes, } \\
\text { drink } 1 \text { cup } 3 \times / \text { Day. }\end{array}$ & 2 & 0.02 & Impotence, fever & 0.3 \\
\hline & & $\begin{array}{l}\text { R15: Decoction of a handful of stem bark in } \\
2 \text { L of water for } 30 \text { minutes, drink } 2 \times / D / \\
14 \text { Day. }\end{array}$ & 1 & 0.02 & & \\
\hline 8 & $\begin{array}{l}\text { Ekebergia } \\
\text { benguelensis }\end{array}$ & $\begin{array}{l}\text { R16: Decoction for } 1 \text { hour of dry root } \\
\text { powder in } 3 \mathrm{~L} \text { of water. Drink } 1 / 2 \text { cup } 3 \mathrm{x} / \\
\text { Day. }\end{array}$ & 1 & 0.08 & $\begin{array}{l}\text { Impotence, malaria, } \\
\text { digestive } \\
\text { dysfunctions }\end{array}$ & 1.6 \\
\hline 9 & $\begin{array}{l}\text { Erythrina } \\
\text { abyssinica }\end{array}$ & $\begin{array}{l}\text { R17: Decoction of two handfuls of powdered } \\
\text { root bark in } 3.5 \text { cups of water for } 30 \\
\text { minutes, drink } 1 \text { cup } 1 \times / \text { Day. }\end{array}$ & 1 & 0.02 & $\begin{array}{l}\text { Anorgasmia, tooth } \\
\text { decay, hepatitis, } \\
\text { fever, sores }\end{array}$ & 0.7 \\
\hline 10 & $\begin{array}{l}\text { Fagara } \\
\text { zanthoxyloides }\end{array}$ & $\begin{array}{l}\text { R18: Decoction of two handfuls of roots in } 4 \\
\text { L of water for } 30 \text { minutes, drink } 1 \text { cup } 1 \times / \\
\text { Day. }\end{array}$ & 1 & 0.05 & $\begin{array}{l}\text { Anorgasmia, } \\
\text { Headache }\end{array}$ & 0.5 \\
\hline \multirow[t]{2}{*}{11} & $\begin{array}{l}\text { Gardenia } \\
\text { Tonantis }\end{array}$ & $\begin{array}{l}\text { R19: Infusion of } 20 \mathrm{~g} \text { of dry powder from the } \\
\text { roots } 1 \mathrm{~L} \text { of water. Drink } 1 / 2 \text { cup } 3 \mathrm{x} / \text { day. }\end{array}$ & 0.5 & 0.02 & $\begin{array}{l}\text { Vaginismus, } \\
\text { intestinal worms }\end{array}$ & 0.3 \\
\hline & & $\begin{array}{l}\text { R20: Maceration for } 7 \text { days of } 20 \mathrm{~g} \text { of dry leaf } \\
\text { powder in } 1 \mathrm{~L} \text { of water. Drink } 1 / 2 \text { cup } 3 \mathrm{x} / \\
\text { Day. }\end{array}$ & 0.5 & 0.02 & & \\
\hline 12 & $\begin{array}{l}\text { Hymenocardia } \\
\text { acida }\end{array}$ & $\begin{array}{l}\text { R21: Infusion of } 2 \text { teaspoons of the } \\
\text { powdered roots in } 1 \text { cup of water, drink } 20 \\
\text { minutes before acting. }\end{array}$ & 1 & 0.05 & $\begin{array}{l}\text { Premature } \\
\text { ejaculation, otitis }\end{array}$ & 0.3 \\
\hline
\end{tabular}




\begin{tabular}{|c|c|c|c|c|c|c|}
\hline $\mathbf{N}^{0}$ & Plant species & Aphrodisiac recipe & $\mathbf{F i}$ & FLAP & Indications & $\mathbf{U V}_{\mathbf{P}}$ \\
\hline 13 & $\begin{array}{l}\text { Julbernardia } \\
\text { paniculata }\end{array}$ & $\begin{array}{l}\text { R22: Decoction of two handfuls of roots for } \\
1 \text { hour in } 2.5 \mathrm{~L} \text { of water, drink } 1 / 2 \text { cup } 2 \times / \mathrm{D} \\
\text { / 14Day. }\end{array}$ & 1 & 0.02 & $\begin{array}{l}\text { Delayed } \\
\text { ejaculation, fever }\end{array}$ & 0.3 \\
\hline \multirow[t]{2}{*}{14} & $\begin{array}{l}\text { Pericopsis } \\
\text { angolensis }\end{array}$ & $\begin{array}{l}\text { R23: Maceration for } 24 \text { hours of two } \\
\text { handfuls of ground roots in } 1 \mathrm{~L} \text { of water, } \\
\text { drink } 2 \times / \text { Day. }\end{array}$ & 0.3 & 0.17 & $\begin{array}{l}\text { Anorgasmia, tooth } \\
\text { decay, hepatitis, } \\
\text { fever, otitis }\end{array}$ & 13.4 \\
\hline & & $\begin{array}{l}\text { R24: Decoction of a handful of roots for } 45 \\
\text { minutes in } 1.5 \mathrm{~L} \text { of water, drink a cup } 30 \\
\text { minutes before acting }\end{array}$ & 0.45 & 0.26 & & \\
\hline \multirow[t]{2}{*}{15} & Physalis angulata & $\begin{array}{l}\text { R25: Place a handful of root powder in a } \\
\text { handkerchief and make it a sort of vaginal } \\
\text { implant for } 3 \text { hours before the act }\end{array}$ & 0.5 & 0.03 & $\begin{array}{l}\text { Premature } \\
\text { ejaculation, colds }\end{array}$ & 0.3 \\
\hline & & $\begin{array}{l}\text { R26: Decoction of } 5 \text { tablespoons of root } \\
\text { powder in } 3 \mathrm{~L} \text { of water for } 1 \text { hour and drink } \\
1 / 2 \text { cup } 3 \times / \text { Day for } 2 \text { months. }\end{array}$ & 0.5 & 0.03 & & \\
\hline 16 & $\begin{array}{l}\text { Pterocarpus } \\
\text { tinctorius }\end{array}$ & $\begin{array}{l}\text { R27: Chew a handful of fresh roots } 10 \\
\text { minutes before acting. }\end{array}$ & 1 & 0.03 & $\begin{array}{l}\text { Anorgasmia, sickle } \\
\text { cell, cough }\end{array}$ & 0.3 \\
\hline \multirow[t]{2}{*}{17} & $\begin{array}{l}\text { Schrebera } \\
\text { trichoclada }\end{array}$ & $\begin{array}{l}\text { R28: Decoction of a handful of roots for } 45 \\
\text { minutes in } 2 \mathrm{~L} \text { of water. Cold drink } 1 / 2 \text { cup } \\
3 \mathrm{x} / \text { Day. }\end{array}$ & 0.33 & 0.05 & $\begin{array}{l}\text { Impotence, cough, } \\
\text { gastritis, intestinal } \\
\text { worms }\end{array}$ & 0.8 \\
\hline & & $\begin{array}{l}\text { R29: Infuse a handful of roots in } 2 \mathrm{~L} \text { of water } \\
\text { and let stand until cool. Drink } 1 / 2 \text { cup } 3 \mathrm{x} / \\
\text { Day. }\end{array}$ & 0.67 & 0.11 & & \\
\hline \multirow[t]{3}{*}{18} & $\begin{array}{l}\text { Securidaca } \\
\text { longipedunculata }\end{array}$ & $\begin{array}{l}\text { R30: Infusion of a handful of roots in } 1 \mathrm{~L} \text { of } \\
\text { water, wait } 30 \text { minutes and perform an } \\
\text { enema } 2 \times / \text { Day. }\end{array}$ & 1 & 0.05 & $\begin{array}{l}\text { Premature } \\
\text { ejaculation, sickle } \\
\text { cell anemia }\end{array}$ & 0.3 \\
\hline & & $\begin{array}{l}\text { R31: Decoction of two handfuls of mixture of } \\
\text { stem and root powders }(1: 1) \text { in 3L of water } \\
\text { for one hour. Drink } 1 / 2 \text { cup } 3 x \text { / Day. }\end{array}$ & 1 & 0.05 & & \\
\hline & & $\begin{array}{l}\text { R32: Maceration in } 3 \mathrm{~L} \text { of water of } 50 \mathrm{~g} \text { of the } \\
\text { bark of the stem and the root. Drink } 1 / 2 \text { cup } \\
2 \mathrm{x} / \text { Day (morning and evening). }\end{array}$ & 1 & 0.05 & & \\
\hline \multirow[t]{2}{*}{19} & $\begin{array}{l}\text { Strychnos } \\
\text { cocculoides }\end{array}$ & $\begin{array}{l}\text { R33: Decoction for } 45 \text { minutes of a mixture } \\
\text { of a handful of leaves and a handful of } \\
\text { powdered roots in } 2 \mathrm{~L} \text { of water, drink } 1 \\
\text { teaspoon } 2 \times / \text { Day in } 2 \text { weeks. }\end{array}$ & 0.4 & 0.05 & $\begin{array}{l}\text { Impotence, } \\
\text { diabetes, headache }\end{array}$ & 0.8 \\
\hline & & $\begin{array}{l}\text { R34: Chew a handful of powdered roots } 15 \\
\text { minutes before acting. }\end{array}$ & 0.6 & 0.08 & & \\
\hline \multirow[t]{2}{*}{20} & $\begin{array}{l}\text { Strychnos } \\
\text { stuhlmannii }\end{array}$ & $\begin{array}{l}\text { R35: Decoction for } 1 \text { hour of } 3 \text { handfuls of } \\
\text { root powder in } 3 \mathrm{~L} \text { of water, drink } 1 \text { cup each } \\
\text { evening for } 1 \text { week. }\end{array}$ & 0.13 & 0.02 & $\begin{array}{l}\text { Impotence, } \\
\text { diabetes, digestive } \\
\text { dysfunctions }\end{array}$ & 0.4 \\
\hline & & $\begin{array}{l}\text { R36 : Maceration for } 24 \text { hours of } 3 \text { handfuls } \\
\text { of fresh roots crushed in } 2.5 \mathrm{~L} \text { of water. } \\
\text { Drink a glass twice a day. }\end{array}$ & 0.88 & 0.2 & & \\
\hline 21 & Terminalia mollis & $\begin{array}{l}\text { R37: Decoction for } 1 \text { hour of } 2 \text { handfuls of } \\
\text { roots in } 5 \text { cups of water and make an enema } \\
\text { with the decocted still warm } 2 \times / \text { Day. }\end{array}$ & 1 & 0.11 & $\begin{array}{l}\text { Impotence, } \\
\text { diarrhea }\end{array}$ & 1.1 \\
\hline
\end{tabular}




\subsubsection{Pathologies managed by the plants listed}

The various plants identified during this study are indicated in 22 pathologies including wounds (12), fever (12), dental caries (7), headache (7) and hepatitis (7) constitute the most cited indications apart from sexual dysfunctions (Table 5). The consensus informing factor (FCI) is higher in the management of acne, diarrhea, gastritis, delayed ejaculation, vaginismus, otitis, colds, diabetes, and sickle cell anemia with FCI 1 but the level of informant loyalty (FL) is only higher in the management of sexual impotence $(\mathrm{FL}=0.59)$. In other pathologies, the highest FL is observed for wounds and fever with an FL of 0.35 for each of these pathologies, followed by hepatitis and dental caries with an FL of 0.21 each. Apart from the use-value of pathologies of the sexual dysfunction class (UV $=0.56$ ), the mixed class with a UV of 0.37 and the digestive tract class with a UV of 0.33 respectively occupy the second and third class (Table 5).

Table 4 Indications in which the re-identified and identified plants are involved

\begin{tabular}{|c|c|c|c|c|c|}
\hline Class & Indication & Ei & FL & FCI & $\mathrm{UV}_{\mathrm{C}(\mathrm{N}=75)}$ \\
\hline \multirow[t]{2}{*}{ Integuments } & Acnes & 2 & 0.06 & 1 & 0.19 \\
\hline & Sores & 12 & 0.35 & 0.82 & \\
\hline \multirow[t]{7}{*}{ Digestive tract } & Tooth decay & 7 & 0.21 & 0.83 & 0.33 \\
\hline & Constipation & 4 & 0.12 & 0.67 & \\
\hline & Diarrhea & 4 & 0.12 & 1 & \\
\hline & Gastritis & 2 & 0.06 & 1 & \\
\hline & Cough & 2 & 0.06 & 0 & \\
\hline & Digestive dysfunctions & 3 & 0.09 & 0.67 & \\
\hline & Intestinal worms & 3 & 0.09 & 0.5 & \\
\hline \multirow[t]{5}{*}{ Sexual dysfunction } & Anorgasmia & 14 & 0.41 & 0.69 & 0.56 \\
\hline & Premature ejaculation & 4 & 0.12 & 0.4 & \\
\hline & Delayed ejaculation & 2 & 0.06 & 1 & \\
\hline & Impotence & 20 & 0.59 & 0.63 & \\
\hline & Vaginismus & 2 & 0.06 & 1 & \\
\hline \multirow[t]{3}{*}{ ENT (otolaryngology) } & Headache & 7 & 0.21 & 0.33 & 0.16 \\
\hline & Otitis & 2 & 0.06 & 1 & \\
\hline & Cold & 3 & 0,09 & 1 & \\
\hline \multirow[t]{5}{*}{ Mixed } & Diabetes & 4 & 0.12 & 1 & 0.37 \\
\hline & Sickle cell anemia & 3 & 0.09 & 1 & \\
\hline & Fever & 12 & 0.35 & 0.81 & \\
\hline & Hepatitis & 7 & 0.21 & 0.83 & \\
\hline & Malaria & 2 & 0.06 & 1 & \\
\hline
\end{tabular}

$\mathrm{Ei}=$ Number of citations of an indication, NF = Level of fidelity of the indication (= np / N), FCI = consensus factor of informants, VUc = Use value by class (= number of citations of indication / sum of citations of each indication).

Concerning to the data (Table 5), this study shows that, apart from sexual dysfunctions, traditional medicine practitioners in Kampemba commune, most often use 21 plants for 4 main pathologies, fever, tooth decay, headache, and hepatitis, without having a high degree of consensus in their management unlike acne, diarrhea, gastritis, otitis, colds, diabetes and sickle cell anemia. In the category of sexual dysfunctions, the informants present a greater consensus on the use of these 21 plants in the management of sexual impotence. 


\subsubsection{Characteristics of listed plants for which botanical identification was not possible}

Twelve other plants were cited during this study; however, their biological identification was not possible at the Kipopo herbarium. These plants are named in 5 vernacular languages (Zela, hemba, bemba, luba and wagenia) of which Luba is the most used language (50\%). From these plants come 14 recipes where the root is the most used organ (78.6\%) under 5 methods of preparation (chewing, infusion, maceration, fumigation, and decoction) dominated by the decoction (57.1\%) and administered in 4 forms dominated by drink (Figure 5). The plants Kibanda banda (Wagenia), Katshi busoko (Luba) and Kafupa (Luba) are the most cited with 4 quotes each.

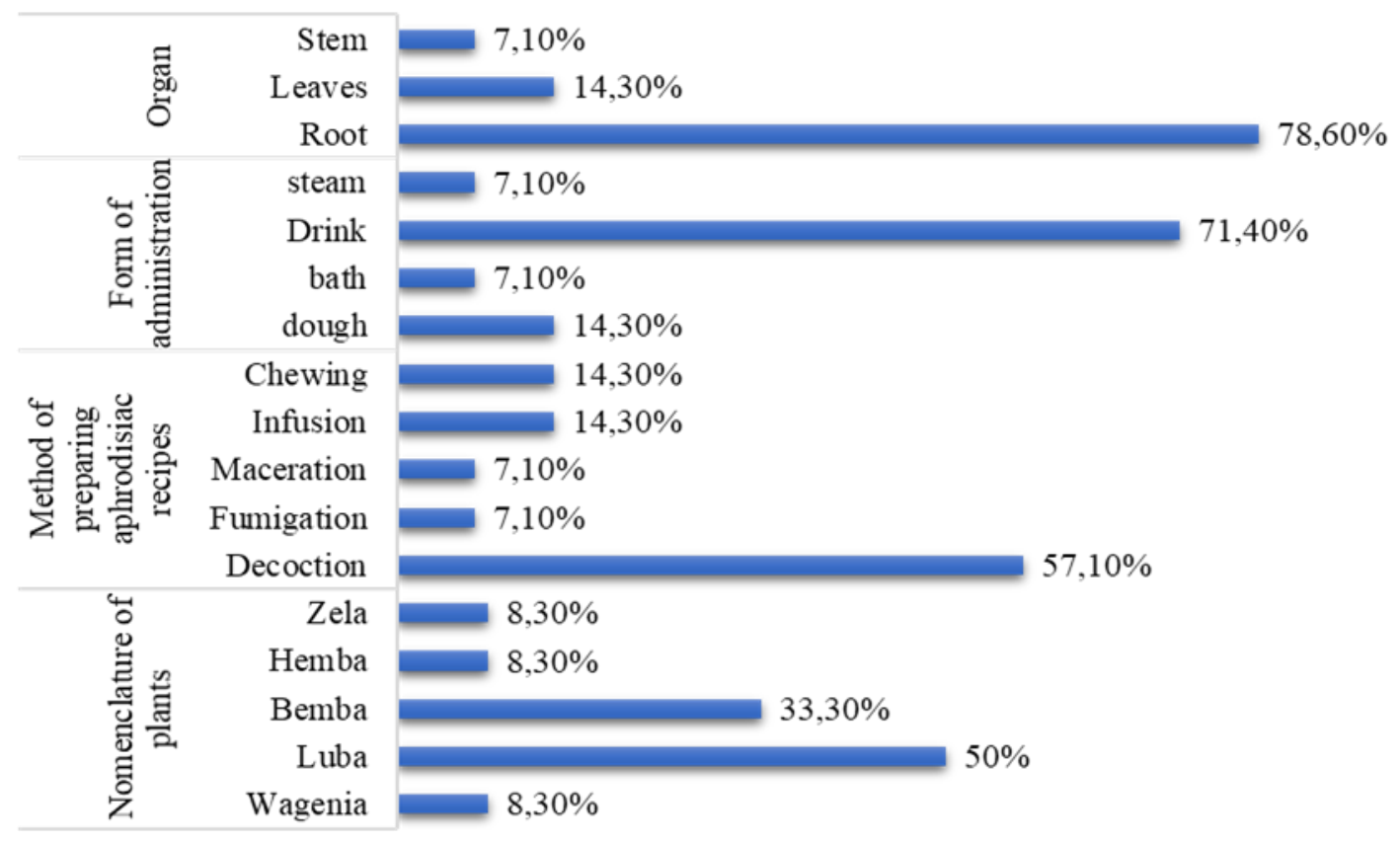

Figure 5 Characteristics of aphrodisiac recipes from non-scientifically identified plants.

The recipes R46 based on the roots of Akokweto (Luba) and R50 based on the bark of roots of Mushirie Mpuya (luba), with 4 quotes each, are the most cited (Table 5). Kibanda banda (Wagenia), Katshi Busoko (Luba), Kafupa (Luba) with 4 pathologies each, are the plants most used by informants in this category of plants.

Table 5 Indications of plants identified but not identified, aphrodisiac recipes and their characteristic indices

\begin{tabular}{|c|c|c|c|c|c|}
\hline $\mathbf{N}^{\circ}$ & Plant species & Aphrodisiac recipe & $\mathbf{E i}$ & Indications & $\mathbf{N i}$ \\
\hline 1 & $\begin{array}{l}\text { Kibanda banda } \\
\text { (Wagenia) }\end{array}$ & $\begin{array}{l}\text { R38: Decoction for } 20 \text { minutes of } 2 \mathrm{~g} \text { of dry root } \\
\text { powder in } 5 \text { cups of water. Drink } 1 / 2 \text { cup } 2 \mathrm{x} / \\
\text { day. }\end{array}$ & 1 & $\begin{array}{l}\text { Impotence, tooth } \\
\text { decay, acne, Gastritis }\end{array}$ & 4 \\
\hline \multirow[t]{2}{*}{2} & $\begin{array}{l}\text { Kavungu meale } \\
\text { (luba) }\end{array}$ & $\begin{array}{l}\text { R39: Decoction for } 1 \text { hour of a handful of root } \\
\text { powder in } 5 \text { cups of water for } 35 \text { minutes; drink } \\
1 / 2 \text { cup } 3 \times / \text { day. }\end{array}$ & 1 & $\begin{array}{l}\text { Impotence, } \\
\text { fever }\end{array}$ & 3 \\
\hline & & $\begin{array}{l}\text { R40: Decoction for } 50 \text { minutes of a mixture of } \\
\text { powders in equal proportion from root and } \\
\text { leaves; drink } 1 \text { cup every night for } 2 \text { weeks. }\end{array}$ & 1 & & \\
\hline \multirow[t]{2}{*}{3} & $\begin{array}{l}\text { Kikele mutshi } \\
\text { (Luba) }\end{array}$ & $\begin{array}{l}\text { R41: Fumigation the } 3 \text { handfuls of leaf powder } 30 \\
\text { minutes before acting out. }\end{array}$ & 1 & $\begin{array}{l}\text { Impotence, cough, } \\
\text { intestinal worms }\end{array}$ & 3 \\
\hline & & $\begin{array}{l}\text { R42: Decoction for } 30 \text { minutes of a few roots in } \\
10 \text { cups of water; drink } 1 / 2 \text { cup } 2 \times / \text { day for } 1 \\
\text { week. }\end{array}$ & 2 & & \\
\hline
\end{tabular}




\begin{tabular}{|c|c|c|c|c|c|}
\hline $\mathbf{N}^{\circ}$ & Plant species & Aphrodisiac recipe & $\mathbf{E i}$ & Indications & $\mathbf{N i}$ \\
\hline 4 & $\begin{array}{l}\text { Katshi Busoko } \\
\text { (Luba) }\end{array}$ & $\begin{array}{l}\text { R43: Maceration of a glass of the root powder in } \\
\text { 3L of water for } 24 \text { hours. enema } 1 \text { hour before the } \\
\text { act. }\end{array}$ & 1 & $\begin{array}{l}\text { Impotence, Colds, } \\
\text { headache, fever }\end{array}$ & 4 \\
\hline 5 & $\begin{array}{l}\text { Tambomutshi } \\
\text { (bemba) }\end{array}$ & $\begin{array}{l}\text { R44: Decoction of } 2 \text { handfuls of roots in } 4 \text { cups of } \\
\text { water; drink } 1 \text { cup a few minutes before acting. }\end{array}$ & 1 & $\begin{array}{l}\text { Impotence, } \\
\text { constipation }\end{array}$ & 3 \\
\hline 6 & $\begin{array}{l}\text { Ilala } \\
\text { (Hemba) }\end{array}$ & $\begin{array}{l}\text { R45: Disperse } 1 \text { or } 2 \text { tbsp in the porridge (the } \\
\text { equivalent of a dessert spoonful) or in a cup of } \\
\text { tea; take each morning on an empty stomach. }\end{array}$ & 3 & $\begin{array}{l}\text { Impotence, diarrhea, } \\
\text { gastritis }\end{array}$ & 3 \\
\hline 7 & $\begin{array}{l}\text { Akokweto } \\
\text { (Luba) }\end{array}$ & $\begin{array}{l}\text { R46: Infusion of } 2 \text { tsp of dry powder from the } \\
\text { roots in a cup of water; drink } 1 \text { cup a few minutes } \\
\text { before acting. }\end{array}$ & 4 & $\begin{array}{lr}\text { Frigidity, } & \text { sexual } \\
\text { impotence, } & \text { gastritis, } \\
\text { sore }\end{array}$ & 3 \\
\hline 8 & $\begin{array}{l}\text { Kahimahima } \\
\text { (Bemba) }\end{array}$ & $\begin{array}{l}\text { R47: Decoction for } 20 \text { minutes of the dry root } \\
\text { reduced to powder in } 1 \mathrm{~L} \text { of water; drink } 10 \mathrm{cc} \\
\text { then chew a stem of the roots before acting } 50 \\
\text { minutes. }\end{array}$ & 2 & $\begin{array}{l}\text { Frigidity, sickle cell } \\
\text { anemia }\end{array}$ & 2 \\
\hline 9 & Kafupa (Luba) & $\begin{array}{l}\text { R48: Chewing a few raw roots } 2 \text { hours before } \\
\text { acting. }\end{array}$ & 1 & $\begin{array}{l}\text { Frigidity, tooth decay, } \\
\text { acnes, sickle cell } \\
\text { anemia }\end{array}$ & 4 \\
\hline 10 & $\begin{array}{l}\text { Kalamata } \\
\text { (Bemba) }\end{array}$ & $\begin{array}{l}\text { R49: Root chewing about } 30 \text { minutes before } \\
\text { acting. }\end{array}$ & 3 & $\begin{array}{l}\text { Anorgasmia, cough, } \\
\text { constipation }\end{array}$ & 3 \\
\hline 11 & $\begin{array}{l}\text { Mushirie } \\
\text { mpuya (luba) }\end{array}$ & $\begin{array}{l}\text { R50: Infusion of } 2 \text { teaspoons of the root bark in a } \\
\text { cup of water; drink once a day for } 5 \text { days. }\end{array}$ & 4 & $\begin{array}{l}\text { Anorgasmia, diarrhea, } \\
\text { gastritis }\end{array}$ & 3 \\
\hline 12 & $\begin{array}{l}\text { Kasomalwa } \\
\text { (Zela) } \\
\text { Bupulukusu } \\
\text { (Bemba) }\end{array}$ & $\begin{array}{l}\text { R51: Decoction for } 20 \text { minutes of the dry root } \\
\text { reduced to powder in } 1 / 2 \mathrm{~L} \text { of water. Drink } 1 / 2 \text { cup } \\
2 \mathrm{x} / \text { day after every } 12 \text { hours. }\end{array}$ & 1 & $\begin{array}{l}\text { Delayed ejaculation, } \\
\text { hepatitis, colds }\end{array}$ & 3 \\
\hline
\end{tabular}

\section{Discussion}

Thanks to 34 PMT, this study highlights 33 plants used in traditional medicine in Kampemba, Lubumbashi-DRC in the management of erectile dysfunction, a health problem that overwhelms a large fraction of the adult Congolese population.

In several ethnobotanical studies carried out in Lubumbashi $[17,19,33,34]$ as well as in this study (table 1), it is showed that men over 40 years are the most encountered during the survey, and their level of education is very low. On the other hand, in some surveys conducted in North Africa [35,36], women are the majority in the practice of traditional medicine. It is possible that the proportion of women who speak out on an issue in traditional medicine is influenced by the subject himself, and in this case, sexual dysfunctions is more easily discussed topic in men than in women.

The tree is the predominant morphological type of plants identified during this study (figure 2) as an ethnobotanical study previously carried out in the same region on antimalarial plants [37]. In contrast, in several studies carried out in Cameroon, the predominant morphological type is grass [38,39]. We could suggest that the tree is the predominant morphological type in traditional medicine in Lubumbashi, and this would be influenced by the type of flora encountered in our region which is mainly the miombo forest. However, more study is needed to generalize this observation. Regarding biological types, the results of this study agree with a study carried out in Chad [40]; but disagree with a study carried out in Lubumbashi [37]. It would be more interesting to carry out a large-scale study to determine the dominant biological types in plant species used in traditional medicine in Lubumbashi. Besides, having collected more plants at Kafubu is related to the fact that this area is located near the rural areas where the vegetation itself has not yet experienced advanced deforestation unlike other areas of the city where planning has promoted deforestation[41]. 
The preponderance of Fabaceae as the botanical family in this study (figure 3) is also reported in many ethnobotanical surveys conducted in Haut-Katanga [19,37,42], and this in opposition with several studies carried out in other regions of the continent $[43,44]$.

The plants under examination are named in 6 vernacular languages (figure 3), Bemba, Hemba, Lamba, Luba, Tshiluba and, Zela, natives of the DRC unless Tshiluba is not from the city of Lubumbashi and Bemba is the most cited language (Table 2). These results are following in accordance with previous ethnobotanical studies carried out in the region $[37,42]$. The predominance of Bemba is said to be linked to two factors, notably the fact that they are among the majority ethnic groups in the region and the fact that traditional medicine is culturally developed in this ethnic group.

Regarding the knowledge reported in the literature (Table 2), these 21 plants can be grouped into 4 classes (Figure 3) among which, Classes A and B represent more than $75 \%$ of species (Figure 3d). Class A includes 8 species reported as aphrodisiacs and medicinal plants from the region; Class B contains only one specie, Julbernardia paniculata (Benth.) Troupin (Fabaceae), which has never been reported in the literature, or as an aphrodisiac plant, much less as a medicinal plant. Class C contains 5 species including Asparagus plumosus Bak. (Asparagaceae), Ekebergia benguelensis Welw. Ex. CDC (Meliaceae), Fagara zanthoxyloides Lam (Rutaceae), Gardenia jovis-Tonantis (Welw) Hiern (Rubiaceae) and Physalis angulata L. (Solanaceae); these plants are reported in the literature as aphrodisiacs, but they are not used in the region as medicinal plants. Class D contains 7 species already used in the region as medicinal plants but never reported before either in the region or in the literature as aphrodisiacs. These include Bobgunnia madagascariensis Riensis (Desv) $\mathrm{JH}$ Kirkbr (Fabaceae), Crossopteryx febrifuga (Afzel. Ex G. Don) Benth (Rubiaceae), Erythrina abyssinica Lam. ex DC. (Fabaceae), Pterocarpus tinctorius Welw (Fabaceae), Schrebera trichoclada Welw (Oleaceae), Strychnos stuhlmannii Gilg (Loganiaceae) and Terminalia mollis M.A. Lawson (Combretaceae) (Figure 3d). However, this study reports for the first time, ethnobotanical knowledge on J. paniculata and the aphrodisiac use of 13 plants, A. plumosus, B. madagascariensis, C. febrifuga E. benguelensis, E. abyssinica, F. zanthoxyloides, G. jovis-Tonantis, P. angulata, P. tinctorius, S. trichoclada, $S$. stuhlmannii and T. mollis.

Concerning ethnobotanical indices calculated for the 21 plants (table 3), the level of fidelity (FL) varies between 0.03 and 0.58 and the value of medicinal use (UV) varies between 0.25 and 5. Albizia adianthifolia (Schum.) W. Wight (Fabaceae) with FL 0.58 and UV 0.25 and Pericopsis angolensis (Baker) Meeuwen (Fabaceae) with FL 0.56 and UV 0.25 show the highest levels of fidelity values but the lowest use values. Erythrina abyssinica Lam. ex DC. (Fabaceae) has the highest use value (Table 3). These results suggest that in the commune of Kampemba, praticians of traditional medicine are more in agreement on the use of the plant species A. adianthifolia and P. angolensis as aphrodisiacs although these two species are used the least in the practice of traditional medicine in this environment. On the other hand, E. abyssinica is the most used plant in traditional medicine in this environment. The preponderance of decoction and drink respectively as a mode of preparation and administration route of aphrodisiac recipes observed in this study (Figure 4) are also reported in several ethnobotanical surveys reviewed in Haut-Katanga [19,37,45]. These studies are in contrast with studies carried out in other regions of the continent [43,44]. In many ethnobotanical studies, the leaf is the most used organ in traditional medicine [46-50], but this study indicates the root as the most used organ (Figure 4) as in surveys of aphrodisiac plants conducted in India [51], Nigeria [25] and Mali [52]. Aside from the fact that the root constitutes a storage organ where several secondary metabolites with various therapeutic properties can be encountered, it symbolizes power, according to the people surveyed. This conception would predispose informants to resort to the root in cases of sexual impotence than in other pathologies.

\section{Highlights}

- Several Congolese suffer from erectile dysfunction and resort to traditional medicine.

- 33 plants, mostly trees of the Fabaceae family, are used in the treatment of erectile dysfunction in Kampemba.

- $\quad$ Albizia adianthifolia (Schum.) W. Wight (Fabaceae) and Pericopsis angolensis (Baker) Meeuwen (Fabaceae) are the most used species.

\section{Conclusion}

This study reports 33 plants used in Kampemba as aphrodisiacs; 12 of them could not be botanically identified. Some of these 33 plants, such as Albizia adianthifolia (Schum.) W. Wight (Fabaceae), have been reported previously in other regions as aphrodisiac plant. Other species such as Julbernadia paniculata (Benth.) Troupin (Fabaceae) are reported for the first time and have a very significant medicinal use-value in Kampemba. Among sexual dysfunctions, most of these plants treat sexual impotence. These results suggest that further work is needed to establish scientific bases for aphrodisiac use of these plants in traditional medicine and to identify the remaining 12 species botanically. 


\section{Compliance with ethical standards}

\section{Acknowledgments}

The authors thank the traditional healers who agreed to share their knowledge as well as Ir Débé Mbungu of Kipopo herbarium for his collaboration in the scientific identification of plants; Disengi Kapumba for completing data.

\section{Disclosure of conflict of interest}

The authors declare that they have no known competing financial interests or personal relationships that could have appeared to influence the work reported in this paper.

\section{References}

[1] Ajit A, Grover S, Rao TSS. Clinical Practice Guidelines for Management of Sexual Dysfunction. Indian J Psychiatry. 2017; 59(S1): S91-115.

[2] Goel B, Maurya NK. Aphrodisiac Herbal therapy for Erectile Dysfunction. Arch Pharma Pr. 2020; 11(1): 1-6.

[3] Nwafor PA, Oniyide VK. Aphrodisiac Effects of Methanol Extract of Smilax Kraussiana Root in Experimental Rats. Afr J Biomed Res. 2017; 20(1): 65-73.

[4] Chapa HO, Fish JT, Hagar C, Wilson T, Chapa HO, Fish JT, et al. Prevalence of female sexual dysfunction among women attending college presenting for gynecological care at a university student health center. J Am Coll Heal. 2018; 1(1): 1-9.

[5] Simons J, Carey MP. Prevalence of Sexual Dysfunctions:Results from a Decade of Research. Arch Sex Behav. 2014; 30(2): 177-219.

[6] Rendell MS, Rajfer J, Wicker PA, Smith MD. Sildenafil for Treatment of Erectile. JAMA. 1999; 281(5): 421-426.

[7] Kumar BS, Kumar JV, Selvaraj R. Aphrodisiac activity of cycas circinalis . I and ionidium suffruticosum . ging on male wister albino rats. Asian J Pharm Clin Res. 2013; 6(3): 10-12.

[8] Togola I, Dembélé J, Daou C, Dénou A, Diarra N, Badiaga M, et al. Ethnobotanical Survey and Phytochemical Screening of Some Plants used in the Management of Erectile Dysfunction in Bwatun ( Mali ) Ethnobotanical Survey and Phytochemical Screening of Some Plants used in the Management of Erectile Dysfunction in Bwatun. 2020; 9(1): 1-8.

[9] Adeyemi OI, Ige 00, Agbede E. The effect of tardalafil on the aphrodisiac properties of Allium sativum and Allium cepa using behavioural models in rats. Nig J Nat Prod Med. 2017; 21(1): 14-20.

[10] Wattanathorn J, Wannanon P, Muchimapura S, Thukham-mee W, Tong-un T, Polyiam P. Toxicity Evaluation of Anacardium occidentale , the Potential Aphrodisiac Herb. BioMed Res Int. 2019; 1(1): 1-20.

[11] Jahan S, Azad T, Ayub A, Ullah A, Afsar T, Almajwal A, et al. Ameliorating potency of Chenopodium album Linn . and vitamin $\mathrm{C}$ against mercuric chloride-induced oxidative stress in testes of Sprague Dawley rats. Environ Health Prev Med. 2019; 24(62): 1-13.

[12] Lert-amornpat T, Fungfuang C, Maketon W. Effect of Kaempferia parviflora on sexual performance in induced diabetic male rats. Andragogia. 2017; 1(1): 1-6.

[13] Houéhanou D., Assogbadjo A., Chadare F., Zanvo S, Sinsin B. Approches méthodologiques synthétisées des études d'ethnobotanique quantitative en milieu tropical. Ann des Sci . 2016; 20(1): 187-205.

[14] Maroyi A. Albizia Adianthifolia : Botany, Medicinal Uses, Phytochemistry, and Pharmacological Properties. The Scientific World Journal 2018, 1-18.

[15] Amuri B, Maseho M, Simbi L, Okusa P, Duez P, Byanga K. Hypoglycemic and Antihyperglycemic Activities of Nine Medicinal Herbs Used as Antidiabetic in the Region of Lubumbashi (DR Congo ). 2017; 31(7): 1029-1033.

[16] Mamedov N, Egamberdieva D. Pharmacology and Therapeutic Uses. In: Munir Ozturk Khalid Rehman Hakeem (Eds) Plant and Human Health , Volume 3 Pharmacology and Therapeutic Uses. 2018; 385.

[17] Muya K, Tshoto K, Cioci CC, Aseho MM, Kalonji M, Byanga K, et al. Survol ethnobotanique de quelques plantes utilisées contre la schistosomiase urogénitale à Lubumbashi et environs. Phyothérapie. 2014; 12: 213-228. 
[18] Mbayo KM, Kalonda ME, Tshisand TP, Kisimba KE, Mulamba M, Richard MK, et al. Contribution to ethnobotanical knowledge of some Euphorbiaceae used in traditional medicine in Lubumbashi and its surroundings ( DRC ). J Adv Bot Zool. 2016; 4(2): 1-16.

[19] Amuri B, Maseho M, Lumbu S, Pierre D, Byanga K. Ethnobotanical survey of herbs used in the management of diabetes mellitus in Southern Katanga Area/DR Congo. Pan African Med Journal. 2018; 30(218): 1-13.

[20] Sachan AK, Das DR, Dohare SL, Shuaib M. Asparagus racemosus (Shatavari): An Overview. Int J Pharm Chem Sci. 2012; 1(3): 588-592.

[21] Bashige CV, Manya-Mboni H, Ntabaza-Ndage V, Numbi Ilunga E, Bakari-Amuri S, Kalonda Mutombo E, et al. Ethnobotany, biological and chemical study of plants used as anti-cariogenic in Lubumbashi - RD Congo. . 2017;15(1): 2-9.

[22] Ajao AA, Sibiya NP, Moteetee AN. Sexual prowess from nature: A systematic review of medicinal plants used as aphrodisiacs and sexual dysfunction in sub-Saharan Africa. South African J Bot. 2019; 122: 342-359.

[23] Mbayo MK, Kalonda EM, Muya RK, Tshisand PT, Kanangila AB, Maseho FM, et al. Test d'activité antimitotique et étude chimique préliminaire de quelques Euphorbiaceae du Katanga méridional (RDC). Phytotherapie 2016; 113.

[24] Maroyi A. An ethnobotanical survey of medicinal plants used by the people in Nhema communal area, Zimbabwe. J Ethnopharmacol. 2011; 136(2): 347-354.

[25] Yusuf HK, Orach-Meza FL, Aliyu BS. Ethnobotanical Inventory of Medicinal Plants With Aphrodisiac Potentials in Katsina. JORIND. 2019; 17(1): 169-180.

[26] Kakeya M. Curing ritual of the Tongwe traditional doctor: its progress and logic. Afr Study Monogr 1982; 55(1): 105-139.

[27] Sabo S, Otimenyin S, Uguru M, Bukar B. Ethnobotanical Survey of Medicinal Plants Used as Aphrodisiacs in Bauchi Local Government Area. J Complement Altern Med Res, 2018; 4(4): 1-13.

[28] Kumwimba LRT, ABaysande WL, Aamba BM, Kikumbi KB, Mbayo KM, Ngoy KE, et al. Quelques plantes utilisées contre des maladies des chèvres dans les territoires de Kalemie et de Moba (RDC). Livest Res Rural Dev. 2017; 29(3): 1-9.

[29] Chingwaru C, Tanja B, Chingwaru W. Aqueous Extracts of Pericopsis angolensis and Swartzia madagascariensis with High Antimicrobial Activities against Escherichia coli 0157, Shigella spp. and Salmonella enterica subsp. enterica (Serovar typhi). African J Biotechnol. 2019; 18(29): 831-844.

[30] Ukwubile CA, Bingari MS, Angyu AE, Garba LC. Physalis angulata Linn. ( Solanaceae ) Leaf Extract Boosts Fertility , Sperm Production and Haematological Parameters in Swiss Male Albino Rats. Int J Med Plants Nat Prod. 2018; 4(3): 1-10.

[31] Mongalo NI, McGaw LJ, Finnie JF, Staden J Van. Securidaca longipedunculata Fresen (Polygalaceae): A review of its ethnomedicinal uses, phytochemistry, pharmacological properties and toxicology. J Ethnopharmacol. 2015; 165: 215-226.

[32] Maroyi A, Cheikhyoussef A. A comparative study of medicinal plants used in rural areas of Namibia and Zimbabwe. Indian J Tradit Knowl. 2015; 14(3): 401-406.

[33] Bashige CV, Manya-Mboni H, Ntabaza-Ndage V, Numbi Ilunga E, Bakari-Amuri S, Kalonda Mutombo E, et al. Étude ethnobotanique, biologique et chimique de plantes réputées anticariogènes à Lubumbashi - RD Congo. Phytotherapie. 2017; 15(1): 2-9.

[34] Mbuyi KS, Kalunga MR, Kalonda M, Cimanga CC, Numbi WI, Kahumba BJ, et al. Aperçu ethnobotanique de plantes réputées antipaludéennes utilisées dans la ville de Lubumbashi et ses environs, dans le Haut-Katanga en RD Congo. Ethnopharmacologia. 2019; 61: 75-83.

[35] Ounaissia K, Smati D, Laredj H, Djafer R, Boualam S. Ounaissia et al. Plantes Cicatrisantes Utilisées en Médecine Traditionnelle dans l'Est Algérien _ Zenodo. Alger J Nat Prod. 2016; 4(3): 663-678.

[36] Kefifa A, Saidi A, Hachem K, Mehalhal O. An Ethnobotanical Survey and Quantitative Study of Indigenous Medicinal Plants Used in the Algerian Semi-arid Region. Phytothérapie. 2019.

[37] Kalonda E, Mbayo M, Muhume S, Kasereka M, Mulamba J, Manya H, et al. Ethnopharmacological survey of plants used against malaria in Lubumbashi city (D.R. Congo). J Adv Bot Zool. 2014; 1(2): 1-8. 
[38] Mpondo EM, Dibong SD, Pouha M. Etude Ethnobotanique des plantes médicinales utilisées dans le département du Haut-Nkam ( Sud Cameroun ). Int J Innov Appl Stud. 2017; 21(4): 574-595.

[39] Etame-Loe G, Ngoule CC, Mbome B, Pouka CK, Ngene JP, Yinyang J, et al. Contribution a l'étude des plantes médicinales et leurs utilisations traditionnelles dans le département du Lom et Djerem (Est, Cameroun). J Anim \&Plant Sci. 2018; 35(1): 5560-5578.

[40] Melom S, Elisée M, Brahim BA, Pierre M. Caractéristiques floristique et écologique des formations végétales de Massenya au Tchad (Afrique centrale ). J Anim \&Plant Sci. 2015; 25(1): 3799-3813.

[41] Sikuzani U, Sambiéni K, Maréchal J, Ilunga wa Ilunga E, Malaisse F, Bogaert J, et al. Changes in the Spatial Pattern and Ecological Functionalities of Green Spaces in Lubumbashi (the Democratic Republic of Congo) in Relation With the Degree of Urbanization. Trop Conserv Sci. 2018; 11.

[42] Bashige CV, Bakari-Amuri S, Mbuyi-Kalonji S, Kahumba-Byanga J, Duez P, Lumbu-Simbi JB. Étude ethnobotanique, phytochimique et évaluation de l'activité antiplasmodiale de 13 plantes réputées antipaludéennes dans la commune du Kenya (Lubumbashi, RDC). Phytotherapie. 2017; 1-10.

[43] Rafieian-Kopaei M, Karami N, Abbaszadeh S, Abbasi N, Bahmani M. Medicinal Plants for Treatment Kidney Stones, An ethnobotany Study in Shahrekord. Egypt J Vet Sci. 2019; 50(2): 145-149.

[44] Yebouk C, Redouan FZ, Benítez G, Bouhbal M, Kadiri M, Boumediana AI, et al. Ethnobotanical study of medicinal plants in the Adrar Province, Mauritania. J Ethnopharmacol. 2020; 246:112217.

[45] Bashige-Chiribagula V, Bakari-Amuri S, Mbuyi-Kalonji S, Kahumba-Byanga J, Duez P, Lumbu-Simbi JB. Study of the ethnobotanical, phytochemical, and antiplasmodial activity of thirteen medicinal plants used against malaria in Kenya commune (Lubumbashi, RDC). Phytotherapie. 2017.

[46] Abubakar IB, Ukwuani-Kwaja AN, Garba AD, Singh D, Malami I, Salihu TS, et al. Ethnobotanical study of medicinal plants used for cancer treatment in Kebbi state, North-west Nigeria. Acta Ecol Sin 2020.

[47] Idm'hand E, Msanda F, Cherifi K. Ethnobotanical study and biodiversity of medicinal plants used in the Tarfaya Province, Morocco. Acta Ecol Sin. 2020; 40(2): 134-144.

[48] Schultz F, Anywar G, Wack B, Quave CL, Garbe LA. Ethnobotanical study of selected medicinal plants traditionally used in the rural Greater Mpigi region of Uganda. J Ethnopharmacol. 2020; 256: 112742.

[49] Setshego MV, Aremu AO, Mooki O, Otang-Mbeng W. Natural resources used as folk cosmeceuticals among rural communities in Vhembe district municipality, Limpopo province, South Africa. BMC Complement Med Ther. 2020; 20(1): 1-16.

[50] Tesfaye S, Belete A, Engidawork E, Gedif T, Asres K. Ethnobotanical Study of Medicinal Plants Used by Traditional Healers to Treat Cancer-Like Symptoms in Eleven Districts, Ethiopia. Evidence-Based Complement Altern Med. 2020; 1-23.

[51] Singh R, Singh S, Jeyabalan, Ali A. An Overview on Traditional Medicinal Plants as Aphrodisiac Agent. J Pharmacogn Phytochem. 2012; 1(4): 43-56.

[52] Togola I, Dembélé J, Daou C, Dénou A, Diarra N, Badiaga M, et al. Ethnobotanical Survey and Phytochemical Screening of Some Plants used in the Management of Erectile Dysfunction in Bwatun ( Mali ). J Nat Prod Plant Resour. 2020; 9(1): 1-8. 